\title{
NUP98/HOXC13 Fusion Gene
}

National Cancer Institute

\section{Source}

National Cancer Institute. NUP98/HOXC13 Fusion Gene. NCI Thesaurus. Code C99451.

A fusion gene that results from a chromosomal translocation $\mathrm{t}(11 ; 12)(\mathrm{p} 15 ; \mathrm{q} 13)$ which fuses exon 16 of the NUP98 gene with exon 2 of the HOXC13 gene. This rearrangement is associated with acute myeloid leukemia. 